\title{
(2) OPEN ACCESS \\ A case of ramucirumab-induced renal failure with nephrotic-range proteinuria and its pathological findings
}

\author{
Yuta Nakano, ${ }^{1}$ Jiro Kumagai, ${ }^{2}$ Kiyotaka Nagahama ${ }_{1}^{3}$ Hajime Fujisawa ${ }^{1}$
}

\begin{abstract}
'Nephrology, Yokohama City Minato Red Cross Hospital, Yokohama, Japan ${ }^{2}$ Pathology, Yokohama City Minato Red Cross Hospital, Yokohama, Japan

${ }^{3}$ Pathology, Kyorin University, Mitaka, Japan
\end{abstract}

Correspondence to Dr Yuta Nakano; ynakano.kid@tmd.ac.jp

Accepted 25 January 2021

Check for updates

(c) BMJ Publishing Group Limited 2021. Re-use permitted under CC BY-NC. No commercial re-use. See rights and permissions. Published by BMJ.

To cite: Nakano Y, Kumagai J Nagahama K, et al. BMJ

Case Rep 2021:14:e239603.

doi:10.1136/bcr-2020-

239603

\section{SUMMARY}

Ramucirumab-induced renal dysfunction is rarely reported. The pathology of ramucirumab-associated nephropathy in past reports primarily shows thrombotic microangiopathy (TMA) lesions but podocytopathy is not yet known. We report a case of kidney injury induced by ramucirumab in a 71-year-old man with cecal cancer. He was referred to our department for increasing serum creatinine $(\mathrm{Cr})$ levels from $1.08 \mathrm{mg} / \mathrm{dL}$ to $2.56 \mathrm{mg} / \mathrm{dL}$ after changing anticancer drugs from bevacizumab to ramucirumab. He showed nephrotic-range proteinuria (12.1 $\mathrm{g} / \mathrm{gCr}$ ). A renal biopsy revealed endothelial cell injuries, such as TMA and podocytopathy with epithelial cell hyperplasia, which looked like a crescent. After discontinuing ramucirumab, his renal function and proteinuria improved, as seen by his $\mathrm{Cr}$ levels and proteinuria which decreased to $1.74 \mathrm{mg} / \mathrm{dL}$ and $1.21 \mathrm{~g} /$ $\mathrm{gCr}$, respectively, in 3 months. Unlike previous reports, we found that ramucirumab caused podocyte injuries.

\section{BACKGROUND}

Currently, inhibiting vascular endothelial growth factor (VEGF) signalling is one of the most efficient ways to treat cancers. Ramucirumab is a fully humanised monoclonal antibody targeting VEGF receptor-2 (VEGFR-2) and it inhibits downstream signalling. ${ }^{1}$ In the last decade, antiangiogenic agents for solid cancers have caused renal dysfunction. ${ }^{2}$ However, renal dysfunction induced by ramucirumab is rarely reported ${ }^{3}$ and its specific clinical course is still unknown.

We present the case of a 71-year-old man who had acute kidney injury with nephrotic-range proteinuria after ramucirumab administration. Past reports showed only thrombotic microangiopathy (TMA) in renal pathological changes, ${ }^{3}$ but his pathological findings suggested ramucirumab induced TMA and podocytopathy, which included a crescent-like lesion.

\section{CASE PRESENTATION}

A 71-year-old man diagnosed with cecal cancer with lymph node metastasis underwent an ileocecal resection and received chemotherapy. $\mathrm{He}$ completed his therapy and remained stable for the next few years. When imaging studies showed a progressive disease, he restarted chemotherapy with folinic acid, fluorouracil, irinotecan and bevacizumab. With bevacizumab, he showed proteinuria $3+$ in a dipstick test; therefore, he was closely monitored. After a year, because he presented with a progressive disease, bevacizumab was changed to ramucirumab. After 2 weeks, he was admitted to our department because of oedema exacerbation. He had high blood pressure, which was $172 / 83$ $\mathrm{mm} \mathrm{Hg}$, although he had already been taking medication for hypertension. His blood pressure was usually controlled at approximately $150 / 80 \mathrm{~mm}$ $\mathrm{Hg}$ with an angiotensin II receptor blocker and a calcium channel blocker. His weight was $68 \mathrm{~kg}$, although his usual weight was $61 \mathrm{~kg}$. He showed pitting oedema.

\section{INVESTIGATIONS}

The laboratory data (table 1) showed worsening renal function and nephrotic-range proteinuria of $12.1 \mathrm{~g} / \mathrm{gCr}$. Serum creatinine $(\mathrm{Cr})$ levels were increased from $1.08 \mathrm{mg} / \mathrm{dL}$ to $2.56 \mathrm{mg} / \mathrm{dL}$. Serum albumin decreased from $3.9 \mathrm{~g} / \mathrm{dL}$ to $3.2 \mathrm{~g} / \mathrm{dL}$. The kidney sizes were $108 \times 56 \mathrm{~mm}$ (right) and $117 \times 56 \mathrm{~mm}$ (left).

A kidney biopsy was performed. The renal biopsy specimen contained 18 glomeruli. Two glomeruli showed global sclerosis. The mesangial matrix proliferated in all glomeruli, and the mesangial cells partly proliferated. The glomerular basement membrane showed thickening in all glomeruli, and half of them showed a double contour that circumscribed fibrin such as an eosinophilic substance (figure 1A,B). TMA caused these changes. No spike formation was detected. Four glomeruli were collapsed with epithelial cell hyperplasia which looks like a crescent lesion (figure 2A,B). These changes were similar to collapsing glomeruli with a 'pseudocrescent' ${ }^{4}$ which suggested podocytopathy. Immunofluorescence studies indicated positive staining of the glomerular capillaries and mesangium for $\mathrm{C} 3, \mathrm{C} 4$ and $\mathrm{C} 1 \mathrm{q}$. A part of the mesangium was also positive for IgG, IgM and IgA. Electron microscopy revealed endothelial cell hyperplasia and non-specific dense substances around the mesangium. Some of the foot processes vanished, but no podocytes were detached. Tubular atrophy and interstitial fibrosis were observed in approximately half of the total area.

\section{DIFFERENTIAL DIAGNOSIS}

We considered the effect of bevacizumab, which is an anti-VEGF-A drug. In this case, several injections of bevacizumab already caused proteinuria. Bevacizumab may have damaged endothelial cells in the glomeruli. However, it was clear that ramucirumab 


\begin{tabular}{|c|c|c|c|}
\hline & Patient values & Reference range & Interpretation \\
\hline \multicolumn{4}{|l|}{ Blood test } \\
\hline White cell count & $3.610^{9} / \mathrm{L}$ & $3.510^{9}-9.110^{9} / \mathrm{L}$ & Normal \\
\hline Haemoglobin & $115 \mathrm{~g} / \mathrm{L}$ & $113-152 \mathrm{~g} / \mathrm{L}$ & Normal \\
\hline Platelet count & $90 \times 10^{9} / \mathrm{L}$ & $130 \times 10^{9}-369 \times 10^{9} / \mathrm{L}$ & Normal \\
\hline $\mathrm{C}$ reactive protein & $0.1 \mathrm{mg} / \mathrm{dL}$ & $0-0.3 \mathrm{mg} / \mathrm{dL}$ & Normal \\
\hline Albumin & $3.2 \mathrm{~g} / \mathrm{dL}$ & $4-5 \mathrm{~g} / \mathrm{dL}$ & Decreased \\
\hline Total protein & $5.6 \mathrm{~g} / \mathrm{dL}$ & $6.7-8.3 \mathrm{~g} / \mathrm{dL}$ & Decreased \\
\hline Blood urea nitrogen & $32.4 \mathrm{mg} / \mathrm{dL}$ & $6-20 \mathrm{mg} / \mathrm{dL}$ & Normal \\
\hline Creatinine & $1.2 \mathrm{mg} / \mathrm{dL}$ & $0.47-0.79 \mathrm{mg} / \mathrm{dL}$ & Elevated \\
\hline LDL cholesterol & $126 \mathrm{mg} / \mathrm{dL}$ & $70-139 \mathrm{mg} / \mathrm{dL}$ & Normal \\
\hline \multicolumn{4}{|l|}{ Urinary test } \\
\hline Urinary red blood cell & $5-9 / \mathrm{HPF}$ & $<1 / \mathrm{HPF}$ & Elevated \\
\hline Urinary protein & $12.1 \mathrm{~g} / \mathrm{gCr}$ & $<0.15 \mathrm{~g} / \mathrm{gCr}$ & Elevated \\
\hline Bence Jones protein & - & - & Normal \\
\hline $\begin{array}{l}\text { Urinary } \beta 2- \\
\text { microglobulin }\end{array}$ & $6777 \mu \mathrm{g} / \mathrm{L}$ & $0-259 \mu \mathrm{g} / \mathrm{L}$ & Elevated \\
\hline Selectivity index & 0.39 & $<0.2$ (high selectivity) & Elevated \\
\hline
\end{tabular}

$H P F$, high power field; LDL, low-density lipoproteins.

was a key drug because renal failure and pitting oedema had not been shown before its administration.

It is known that bevacizumab mainly causes TMA. ${ }^{5}$ His pathology showed not only TMA but also glomerular collapse with a crescent-like lesion. This also suggested that the renal dysfunction could not be explained only by bevacizumab.

\section{TREATMENT}

We discontinued ramucirumab and continued an angiotensin II receptor blocker to reduce proteinuria. We did not use immune therapies such as corticosteroids.

\section{OUTCOME AND FOLLOW-UP}

After discontinuation of ramucirumab, the serum Cr gradually decreased to $1.79 \mathrm{mg} / \mathrm{dL}$, and proteinuria also decreased to $3.21 \mathrm{~g} / \mathrm{gCr} 3$ months later (figure 3). Proteinuria decreased to $1.21 \mathrm{~g} / \mathrm{gCr}$ about 7 months later.

\section{DISCUSSION}

Many anticancer drugs have been developed to inhibit VEGF signalling because it plays a vital role in controlling neovascular processes in neoplasms. ${ }^{2}$ In the kidney, podocytes and endothelial cells are significant sources of VEGF. It acts in autocrine and paracrine fashions and contributes to maintaining homeostasis. ${ }^{6}$

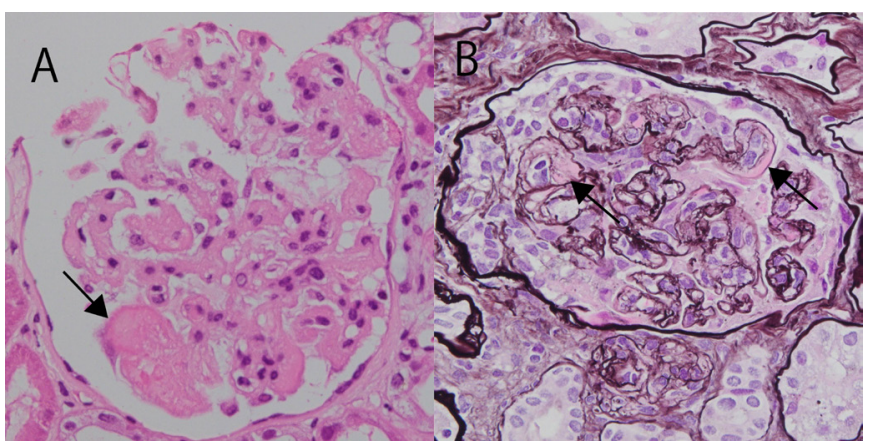

Figure 1 The glomerular basement membrane showed thickening in all glomeruli, and half of them showed a double contour with fibrinous exudates. (A): H\&E stain, (B): Periodic acid-methenamine silver stain).

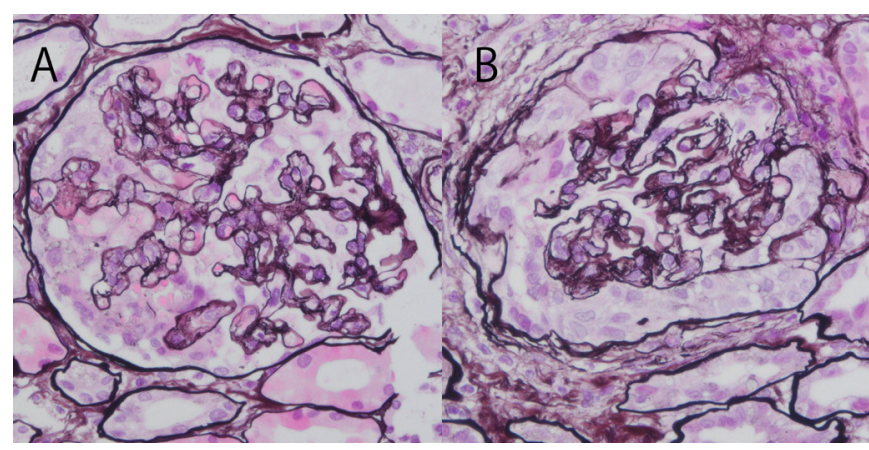

Figure 2 Glomeruli with epithelial cell hyperplasia, which looks like a 'crescent', show capillary wall collapse. (A, B: Periodic acidmethenamine silver stain).

The VEGF receptor family, which is a tyrosine kinase receptor, consists of three subtypes: VEGFR-1, VEGFR-2 and VEGFR-3. Among them, VEGFR-2 is predominantly expressed in podocytes, mesangium, endothelial cells and tubular capillaries. ${ }^{56}$ Ramucirumab is a VEGFR-2 binding monoclonal antibody that has been widely used for gastric, lung and colorectal cancer as a second-line therapy. ${ }^{1}$ A previous study showed adverse renal effects of ramucirumab involving hypertension (21\%) and proteinuria (9\%). ${ }^{7}$ Although other VEGF inhibitory drugs, such as the anti-VEGF monoclonal body (bevacizumab), tyrosine kinase inhibitors (sunitinib, axitinib, sorafenib and cediranib) and VEGF-Trap (aflibercept) have been known to cause nephroticrange proteinuria and renal dysfunction, ramucirumab has been reported in only one case report ${ }^{8}$ and one single-centre case report. $^{3}$

Anti-VEGF/VEGFR therapy reportedly accounts for two primary forms of renal pathological changes: minimal change disease (MCD) or focal segmental glomerulosclerosis (FSGS), which suggests podocytopathy, and TMA, which suggests endothelial cell injury. ${ }^{5}$ There is a different tendency for TMA or MCD/FSGS to occur depending on the type of anti-VEGF/ VEGFR drug. For example, it is well known that VEGFR is abundant in endothelial cells and inhibition of VEGFR-VEGF crosstalk by anti-VEGF drugs, such as bevacizumab cause TMA. ${ }^{5}$ On the other hand, VEGFR tyrosine kinase inhibitors (RTKI) cause MCD/FSGS more often than TMA. Previous studies suggested that RTKI inhibits NF- $\mathrm{KB}$ activity, leading to c-mip overexpression, and induces MCD or FSGS. ${ }^{5}$ In two previous studies on ramucirumab-induced nephropathy, three cases of renal pathology were reported ${ }^{38}$ and all of them were reported as TMA. The development of renal impairment

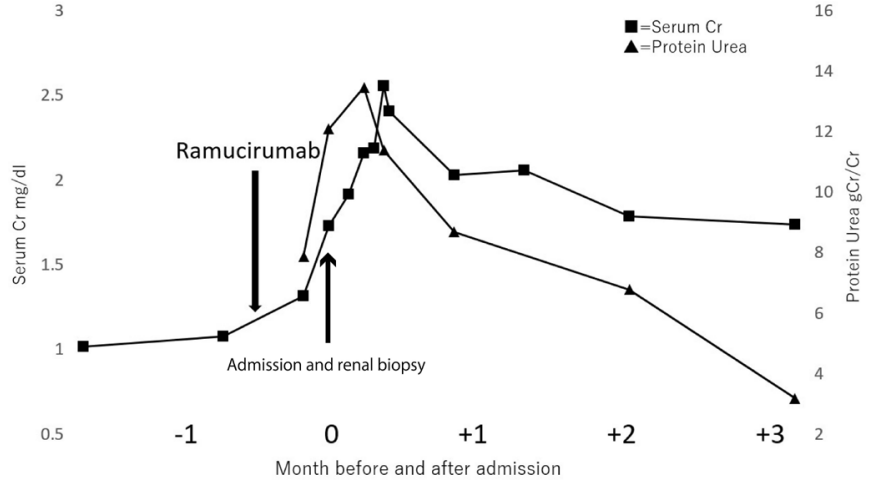

Figure 3 There was an improvement with the discontinuation of the medication, but some renal impairment remained. 
characterised the three previous cases after switching from bevacizumab to ramucirumab, as in this case. It is possible that TMA could be caused or exacerbated due to endothelial damage caused by ramucirumab because it is known that the interaction of VEGF with VEGFR-2 is necessary to maintain endothelial cells. ${ }^{9}$ Since double contours of the glomerular basement membrane were chronic lesions of $\mathrm{TMA}^{10}$ and bevacizumab was administered before ramucirumab, the effect of bevacizumab on TMA could not be ignored. Compared with previous reports, we think this case is characterised by collapsing glomeruli with epithelial cell hyperplasia. A previous report showed that collapsing glomeruli with 'pseudocrescents' are caused by podocyte damage. ${ }^{4}$ The clinical course of marked nephrotic-range proteinuria is also consistent with podocytopathy rather than TMA. A previous study showed that VEGFR-2 is also expressed in podocytes in vivo and that VEGF and VEGFR-2, through autocrine actions, regulate podocyte survival. ${ }^{11}$ Bertuccio et al ${ }^{12}$ demonstrated a direct interaction between VEGFR-2 and nephrin in vitro and proposed VEGF signalling via the VEGFR-2-nephrin complex has an essential role in podocyte foot process effacement.

Moreover, ramucirumab inhibits the start of VEGFR-2 signalling, which is the target of $\mathrm{RTKI}^{7}$ so ramucirumab would cause podocytopathy in the same way as RTKI. These findings suggest that VEGFR-2 plays an important role in podocytes. As mentioned above, renal injury occurred in the three previously reported cases as well as in this case after switching from bevacizumab therapy and this suggests the synergistic effect of ramucirumab and bevacizumab. Müller-Deile et $a l^{6}$ showed that VEGF-A and VEGF-C both interact with VEGFR-2 and play important roles in podocyte survival. They showed that when VEGF-A is inhibited by bevacizumab, VEGF-C plays an important role in suppressing podocyte apoptosis. Another study showed that when bevacizumab inhibits VEGF-A, VEGF-C maintains VEGFR-2 activation in glioblastomas. ${ }^{13}$ In our case, ramucirumab was considered to have inhibited the interaction between VEGFR-2 and VEGF-C, and this may have resulted in a synergistic effect. The pathology of this case suggests that the presence of chronic TMA caused by bevacizumab may have been combined with podocyte damage from ramucirumab, leading to severe damage to the kidney. This case suggests that VEGFR-2

\section{Learning points}

- Compared with other antivascular endothelial growth factor (anti-VEGF) drugs, the pathology of ramucirumab-induced renal failure is still unknown. Only a few reports suggest ramucirumab can present thrombotic microangiopathy, but we found that ramucirumab can also injure podocytes.

- Although rare, ramucirumab can cause severe proteinuria and renal dysfunction with just one dose. When used, we must follow-up carefully.

- If ramucirumab is a possible causative agent, it should be discontinued. As with other VEGF inhibitors, proteinuria and renal impairment may improve with discontinuation.

- Ramucirumab and bevacizumab may have synergistic side effects. Care must be taken when switching between both drugs. plays an essential role in the maintenance of podocytes as well as endothelial cells.

We report a rare case of ramucirumab-induced severe proteinuria and renal dysfunction with just one dose. The pathology showed not only TMA lesions but also collapsing glomeruli with crescent-like lesions due to epithelial cell hyperplasia caused by podocyte injury. Given that ramucirumab can cause podocytopathy, which is uncommon in bevacizumab, the change from bevacizumab to ramucirumab should be made carefully. When ramucirumab is used, proteinuria and renal function should be strictly monitored. We also found that proteinuria and serum Cr levels decreased without corticosteroids after ramucirumab treatment was discontinued. Once ramucirumab causes renal involvement, ramucirumab should be discontinued for some time.

Acknowledgements The authors would like to acknowledge Dr Atsuki Ohashi, Dr Eriko Kanehisa and Dr Megumi Yamamuro for their cooperation in medical practice.

Contributors YN wrote the manuscript with support from HF. JK and KN gave advice about pathological interpretation.

Funding The authors have not declared a specific grant for this research from any funding agency in the public, commercial or not-for-profit sectors.

Competing interests None declared.

Patient consent for publication Consent obtained from next of kin.

Provenance and peer review Not commissioned; externally peer reviewed.

Open access This is an open access article distributed in accordance with the Creative Commons Attribution Non Commercial (CC BY-NC 4.0) license, which permits others to distribute, remix, adapt, build upon this work non-commercially, and license their derivative works on different terms, provided the original work is properly cited and the use is non-commercial. See: http://creativecommons.org/ licenses/by-nc/4.0/.

\section{REFERENCES}

1 Arnold D, Fuchs CS, Tabernero J, et al. Meta-analysis of individual patient safety data from six randomized, placebo-controlled trials with the antiangiogenic VEGFR2binding monoclonal antibody ramucirumab. Ann Oncol 2017;28:2932-42.

2 den Deurwaarder ESG, Desar IME, Steenbergen EJ, et al. Kidney injury during VEGF inhibitor therapy. Neth J Med 2012;70:267-71.

3 Fujii T, Kawasoe K, Tonooka A, et al. Nephrotic syndrome associated with ramucirumab therapy: a single-center case series and literature review. Medicine 2019:98:e16236.

4 Albaqumi M, Soos TJ, Barisoni L, et al. Collapsing glomerulopathy. J Am Soc Nephrol 2006:17:2854-63.

5 Ollero M, Sahali D. Inhibition of the VEGF signalling pathway and glomerular disorders. Nephrol Dial Transplant 2015;30:1449-55.

6 Müller-Deile J, Worthmann K, Saleem M, et al. The balance of autocrine VEGF-A and VEGF-C determines podocyte survival. Am J Physiol Renal Physiol 2009:297:F1656-67.

7 Estrada CC, Maldonado A, Mallipattu SK. Therapeutic inhibition of VEGF signaling and associated Nephrotoxicities. J Am Soc Nephrol 2019:30:187-200.

8 Yamada R, Okawa T, Matsuo K, et al. Renal-limited thrombotic microangiopathy after switching from bevacizumab to ramucirumab: a case report. BMC Nephrol 2019;20:14

9 Izzedine H, Escudier B, Lhomme C, et al. Kidney diseases associated with anti-vascular endothelial growth factor (VEGF): an 8-year observational study at a single center. Medicine 2014:93:333-9.

10 Goodship THJ, Cook HT, Fakhouri F, et al. Atypical hemolytic uremic syndrome and C3 glomerulopathy: conclusions from a "Kidney Disease: Improving Global Outcomes" (KDIGO) Controversies Conference. Kidney Int 2017:91:539-51.

11 Sison $\mathrm{K}$, Eremina V, Baelde $\mathrm{H}$, et al. Glomerular structure and function require paracrine, not autocrine, VEGF-VEGFR-2 signaling. J Am Soc Nephrol 2010;21:1691-701

12 Bertuccio C, Veron D, Aggarwal PK, et al. Vascular endothelial growth factor receptor 2 direct interaction with nephrin links VEGF-A signals to actin in kidney podocytes. J Biol Chem 2011;286:39933-44.

13 Michaelsen SR, Staberg M, Pedersen H, et al. VEGF-C sustains VEGFR2 activation under bevacizumab therapy and promotes glioblastoma maintenance. Neuro Oncol 2018:20:1462-74. 
Copyright 2021 BMJ Publishing Group. All rights reserved. For permission to reuse any of this content visit https://www.bmj.com/company/products-services/rights-and-licensing/permissions/

BMJ Case Report Fellows may re-use this article for personal use and teaching without any further permission.

Become a Fellow of BMJ Case Reports today and you can:

- Submit as many cases as you like

- Enjoy fast sympathetic peer review and rapid publication of accepted articles

- Access all the published articles

- Re-use any of the published material for personal use and teaching without further permission

Customer Service

If you have any further queries about your subscription, please contact our customer services team on +44 (0) 2071111105 or via email at support@bmj.com.

Visit casereports.bmj.com for more articles like this and to become a Fellow 